\title{
Perancangan Mesin Tube Notcher Menggunakan Metode G. Pahl dan W. Beitz
}

\author{
Iqbal R. Pamungkas ${ }^{1}$, Bambang Sulaksono ${ }^{1}$, Megara Munandar ${ }^{1}$, Agri Suwandi ${ }^{1}$, M. Fathur Fajar ${ }^{1}$ \\ ${ }^{1}$ Departemen Teknik Mesin, Fakultas Teknik, Universitas Pancasila, Srengseng Sawah, Jagakarsa, DKI Jakarta 12640, \\ Indonesia \\ iqbal.pamungkas@univpancasila.ac.id
}

\begin{abstract}
ABSTRAK
Mesin tube notcher adalah mesin yang digunakan untuk memotong pipa besi dengan menghasilkan profil pada sisi potongnya yang berfungsi untuk memudahkan proses awal penyambungan pipa besi.Di industri menengah kebawah dibutuhkan mesin tube notcher yang dapat berkerja secara efesien dengan biaya murah.Perancangan ini bertujuan untuk memperoleh rancangan mesintube notcher dengan spesifikasi yang baik, agarrancangan mesin mudah digunakan, tahan lama dan terdapat data rancangan dalam bentuk gambar.Pada perancangan ini menggunakan metode G.Pahl dan W.Beitz meliputi pembuatan daftar persyaratan, struktur fungsi dan prinsip solusi.Kemudian tahap analisa konsep perancangan dengan membuat tabel seleksi varian mesin dan melalui kriteria pembobotan.Hasil yang diperoleh adalah data rancangan berbentuk gambar mesin menggunakan software Pro Engineer.Rangka pada mesin ini adalah baja karbon hollow persegi dan alumunium untuk material komponen-komponennya. Dimensi keseluruhan dalam panjang, lebar dan tinggi adalah $600 \times 400 \times 800 \mathrm{~mm}$ dengan berat $22,187 \mathrm{~kg}$ menggunakan motor penggerak 600 watt.
\end{abstract}

Kata kunci:Mesin Tube Notcher, metode G.Pahl dan W.Beitz, perancangan mesin.

\begin{abstract}
Tube notcher machine is a machine used to cut iron pipes by producing a profile on the cutting side which serves to facilitate the initial process of connecting iron pipes. In the middle and lower industries, a tube notcher machine is needed that can work efficiently at a low cost. This design aims to obtain a tube notcher engine design with good specifications, so that the engine design is easy to use, durable and there are design data in the form of images. In this design using the G.Pahl and W.Beitz methods include making a list of requirements, function structures and solution principles. Then the stage of design concept analysis by creating a machine variant selection table and through weighting criteria. The results obtained are design data in the form of machine images using Pro Engineer software. The frame on this machine is square hollow carbon steel and aluminum for its component materials. The overall dimension in length, width and height is 600 $\times 400 \times 800 \mathrm{~mm}$ with a weight of 22,187 kg using a 600 watt drive motor.
\end{abstract}

Keywords:Tube Notcher, G.PahlandW.Beitz method, machine design.

\section{Pendahuluan}

Melihat proses awal pada penyambungan pipa diperlukan mesin tube notcher, mesin pemotong pipa yang menghasilkan profil pada sisi pemotongannya, hal membuat sambungan lebih rapat dan memudahkan penyambungan pada proses selanjutnya, contohnya pada sambungan pipa besi pada rangka sepeda motor, mesin tube notcher sudah banyak tersedia dipasar dengan berbagai spesifikasi dan macam-macam sistem pemotongannya, akan tetapi penggunaan mesin ini masih terbatas, hanya dikalangan tertentu atau industri besar yang menggunakan mesin ini karena harganya yang mahal, dan apabila ingin memiliki mesin ini harus mengimpor mesin ini dengan biaya yang tidak sedikit, sedangkan pada industri menengah kebawah tidak menggunakan mesin tube notcher melainkan dengan proses manual, mengaplikasikannya pada mesin bubut dan dengan cara lainnya.Untuk mengembangkan mesin ini diperlukan metode perancangan yang sudah ada agar dalam proses pengembangan mesin ini memiliki spesifikasi yang efesien terhadap bahan komponen, kontruksi, komponen-komponen mesin mudah diperoleh, murah dan memiliki standar mutu.

Maka dari itu mesin ini menjadi bahan kajian dalam tugas akhir ini dengan judul perancangan mesin tube notcher dengan metode $G$ Pahl dan W Beitz, karena ingin mencoba membuat rancangan mesin tube notcher dengan rancangan yang sederhana.

Berikut adalah batasan masalah pada penelitian ini:

1. Perancangan konsep menggunakan metode G.Pahl dan W.Beitz

2. Perancangan detail menggunakan software Pro Engineer

3. Analisa perancangan menggunakan perhitungan

4. Hasil dari analisa menyesuaikan dengan standar pasar 


\section{LANDASAN TEORI}

\section{A. Mesin Tube Notcher}

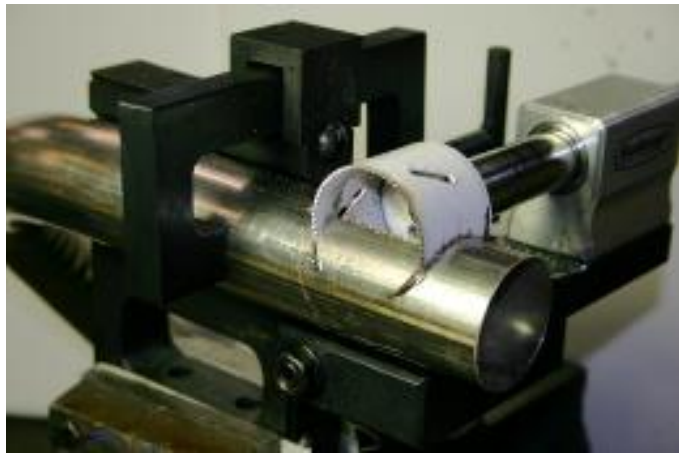

Gambar 1 Tube Notcher[6]
Mesin tube notcer dapat digunakan pada pipa berlekuk, dimana salah satu atau kedua tabung dapat berlekuk sebelum perakitan.Pada rangka sepeda motor yang menggunakan pipa besi dengan disain rangka yang berlekuk yang belum tersambung satu bagian dengan bagian lainnya, diperlukan proses penyambungan yang mudah dan solid, maka dengan memberi profil pada penyambungan pipa merupakan cara yang baik dalam proses awal penyambungan pipa

Material pada Mesin Tube Notcher, terdiri dari:

1. Baja karbon

2. Alumunium

3. Stainless steel

4. Akrilik
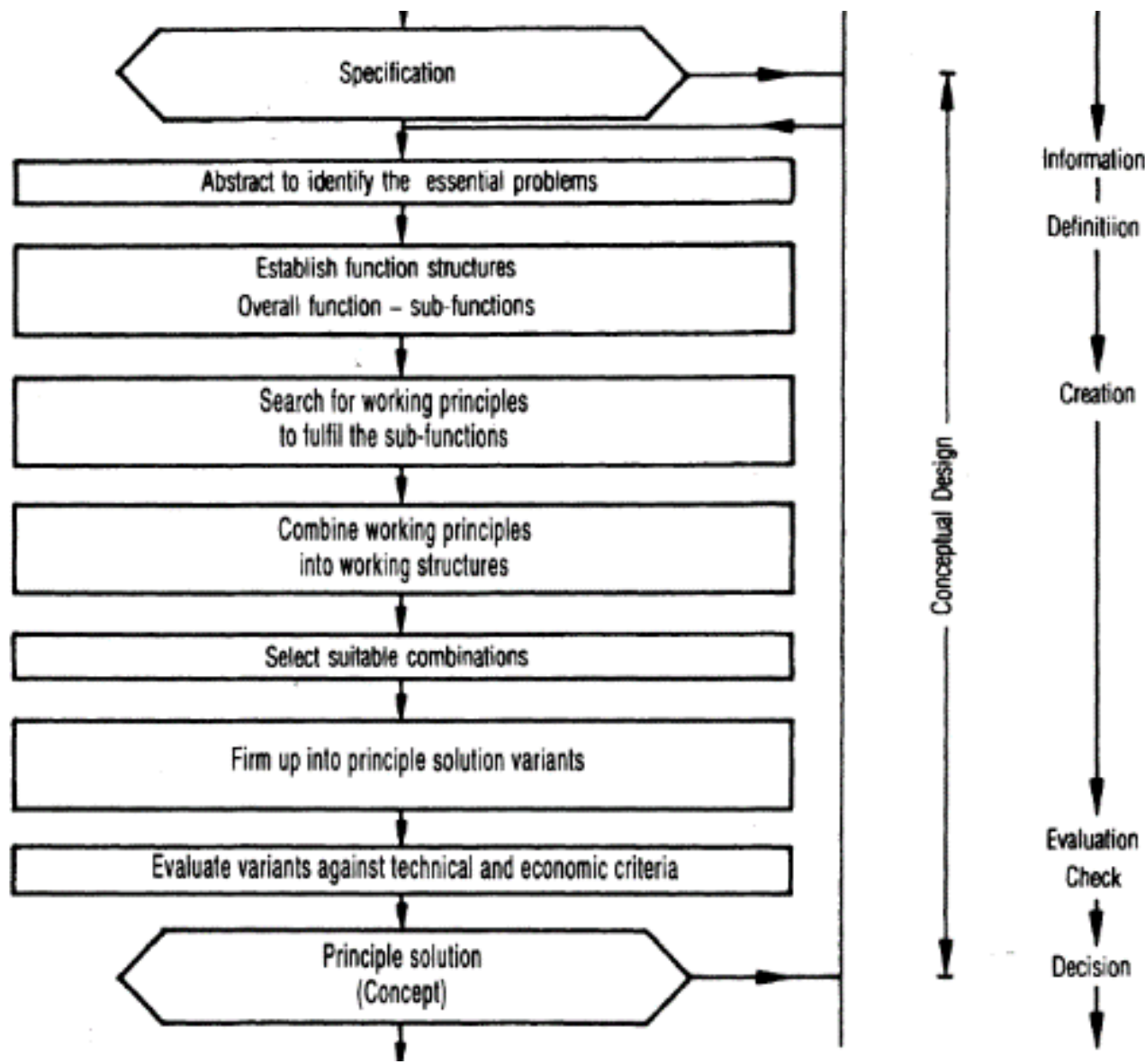

Mesin tube notcer adalah suatu mesin pemotong pipa diantaranya adalah:

Gambar 2 Tahap Konsep Perancangan Pahl, Beitz [1]

yang menghasilkan profil pada sisi pemotongannya dengan cara menyesuaikan ketinggian dan sudut potong sesuai keinginan dengan mengandalkan pisau hole saw khusus dalam mekanisme pemotongannya. Hasil pemotongan oleh mesin ini memudahkan proses awal penyambungan pipa. Pipa besi dipotong sesuai perhitungan sehingga dapat tersusun pas dan erat yang kemudian masuk kedalam proses penyambungan untuk membuat sambungan pipa tee, vee, atau bentuk sambungan lainnya.
1. Motor penggerak

2. Transmisi rantai dan sproket

3. Poros

4. Bantalan

5. Hole Saw

6. Saklar 
Perancangan produk didefinisikan sebagaiproses penyusunan konsep suatu produk baik produk baru maupun produk pengembangan dalam bentuk gambar teknik untuk memenuhi keinginan pelanggan atau untuk memanfaatkan inovasi, perencanaan produk merupakan perencanaan tentang apa, berapa dan bagaimana produk yang akan diproduksi.

Menurut buku engineering design perancangan teknik digambarkan sebagai pusat perpotongan budaya dan aliran rekayasa. Perancangan teknik juga merupakan sebuah aktivitas kreatif dalam cakupan ilmu pengetahuan meliputi matematika, kimia, fisika, thermodinamika, hydrodinamika, teknik elektronika, teknik produksi, teknologi material, elemen mesin dan teori perancangan dan lain-lain. Dan juga memerlukan pengetahuan praktis, pengalaman dan wawasan ekonomi [1].

Disain dikenakan pada bentuk sebuah rencana, dalam hal ini dapat berupa proposal, gambar, model, maupun deskripsi. Jadi dapat dikatan, desain merupakan sebuah konsep tentang sesuatu. Desain lahir dari penerjemahan kepentingan, keperluan, data maupun jawaban atas sebuah masalah dengan metode-metode yang dianggap komprehensif, baik itu riset, brainstorming, pemikiran maupun memodifikasi desain yang sudah ada sebelumnya [2]

Ketepatgunaan dan efektivitas merupakan syarat utama dalam merancang suatu produk. Berbagai macam kebutuhan harus disesuaikan terhadap kondisi perusahaaan, pabrik, publik yang meminta jasa produk tersebut,situasipasar dan perkembangan teknologi.

Pada proses penentuan konsep rancangan ini dibahas bagaimana cara menentukan fungsi dan strukturnya, menguraikan menjadi varian yang dapat direalisasikan, pemilihan kombinasi dan pembuatan varian serta evaluasi. Diharapkan dari tahap penentuan konsep rancangan berikut mulai bisa dilihat gambaran perancangan yang akan terealisasi. Lebih jelas mengenai perancangan konsep dapatlihat dari gambar 2 .

Pada saat membuat daftar persyaratan hal yang penting adalah membedakan sebuah persyaratan, apakah sebagai suatu tuntutan (demand) atau keinginan (whises).Demand adalah persyaratan yang harus terpenuhi pada setiap kondisi atau dengan kata lain apabila persyatan itu tidak terpenuhi maka perancangan dianggap tidak benar. Whises adalah persyaratan yang dinginkan apabila memungkinkan.

Jadi misalkan suatu persyaratan membutuhkan biaya yang cukup tinggi tanpa memberikan pengaruh teknik yang besar, maka persyaratan tersebut dapat diabaikan. Untuk mempermudah penyusunan sepesifikasi dapat dilakukan dengan meninjau aspek-aspek geometri, kinematika, gaya, energi, dan lain sebagainya. Selanjutnya dari aspek dapat diuraikan syarat-syarat yang bersangkutan dan kemudian dibuat daftar spesifikasinya.

\section{KONSEP PERANCANGAN}

Berikut adalah diagram alir penulisan laporan penelitian yang berjudul perancangan mesin tube notcher.

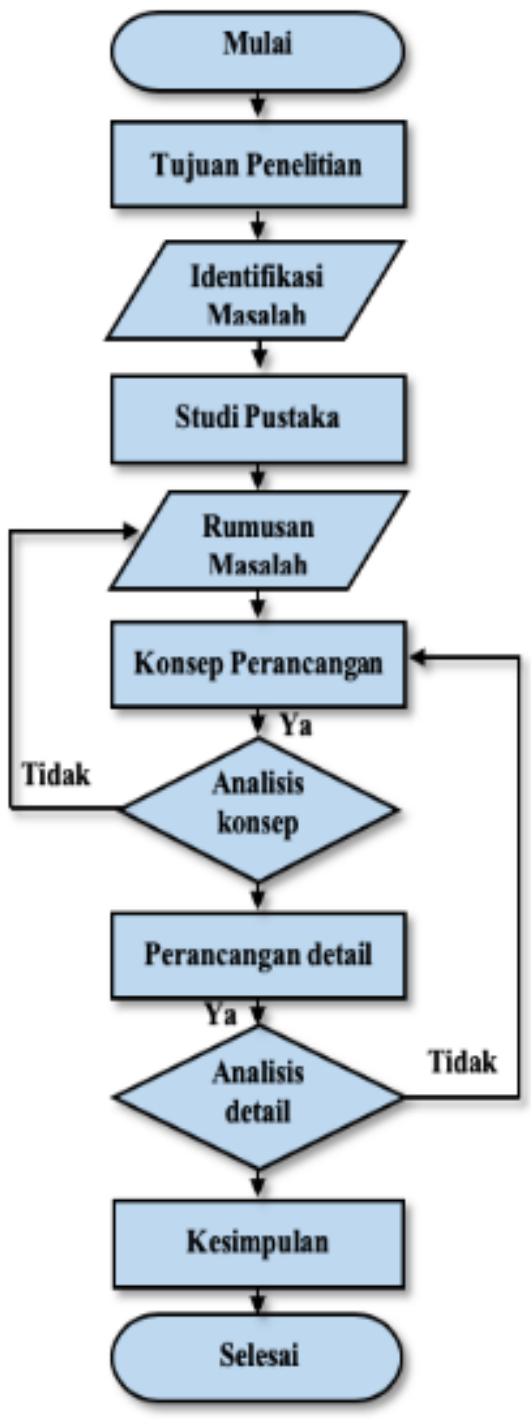

Gambar 1 Diagram Alir

Berikut ini daftar persyaratan mesin tube notcher yang akan dirancang menjadi 2 kategori yaitu D/demand (keharusan) dan W/whises (keinginan).

Tabel 1 Daftar Persyaratan

\begin{tabular}{|c|c|c|}
\hline D-III & DAFTAR & 30/5/17 \\
MESIN & $\begin{array}{c}\text { PERSYARATAN } \\
\text { FT-UP }\end{array}$ & $\begin{array}{c}\text { MEge 1 } \\
\text { NOTCHN TUBE }\end{array}$ \\
\hline$D / W$ & \multicolumn{2}{|c|}{ PERSYARATAN } \\
\hline
\end{tabular}




\begin{tabular}{|c|c|}
\hline & Mesin Tube Notcher \\
\hline$D$ & Geometri \\
\hline$D$ & Dimensi sedang \\
\hline $\boldsymbol{W}$ & Berat ringan \\
\hline $\begin{array}{l}w \\
D\end{array}$ & Bentuk sederhana \\
\hline & Mudah dipindahkan dan disimpan \\
\hline$D$ & Kinematik \\
\hline$D$ & $\begin{array}{l}\text { Jenis gerakan pisau berputar } \\
\text { Arah gerakan pisau yang horizontal }\end{array}$ \\
\hline$D$ & $\begin{array}{l}\text { kecepatan pisau sesuai bahan pisau } \\
\text { dan material yang dikerjakan }\end{array}$ \\
\hline$D$ & $\begin{array}{l}\text { Jenis gerakan penjepit benda kerja } \\
\text { horizontal }\end{array}$ \\
\hline$D$ & Energi \\
\hline$D$ & $\begin{array}{l}\text { Ramah lingkungan } \\
\text { Banyak tersedia }\end{array}$ \\
\hline$D$ & Material \\
\hline$D$ & $\begin{array}{l}\text { Tersedia di pasaran } \\
\text { Memiliki standar }\end{array}$ \\
\hline$D$ & Sinyal \\
\hline & Mudah digunakan \\
\hline & Akurat \\
\hline & Melindungi pengguna \\
\hline & Pelindung mesin \\
\hline & Tombol power \\
\hline & Perawatan \\
\hline & Tidak memerlukan perawatan yang \\
\hline & khusus \\
\hline & Perakitan \\
\hline & Mudah dibongkar pasang \\
\hline & Komponen yang sedikit \\
\hline & Ergonomi \\
\hline & $\begin{array}{l}\text { Pengoperasian secara manual dan } \\
\text { bentuk disain mesin vang terbarukan }\end{array}$ \\
\hline
\end{tabular}

Struktur fungsi berdasarkan hubungan antara input dan output dari suatu sistem teknik yang akan menjalankan mesin tube notcher ini.

\section{Fungsi Keseluruhan}

Fungsi ini digambarkan dengan blok yang menunjukan hubungan antara input dan output.Gambar 4 menggambarkan input dan output pada mesin tube notcher yang akan dirancang.

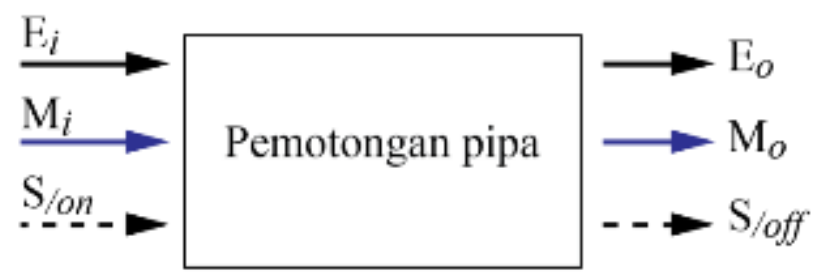

Gambar 2 Fungsi Keseluruhan

Keterangan dari fungsi keseluruhan :

$\boldsymbol{M}$ : Pipa benda kerja masuk

$S_{\text {on/off: Sinyal }}$

$\boldsymbol{M}_{\boldsymbol{o}}$ : Pipa yang sudah jadi keluar

$\mathbf{E}_{i}$ : Energi masuk
$\mathbf{E}_{o}$ :

keluar

Energi

\section{Sub Struktur Fungsi}

Dari analisis diatas, dapatlah ditentukan fungsi-fungsi yang menyusun struktur mesin tube notcher ini.

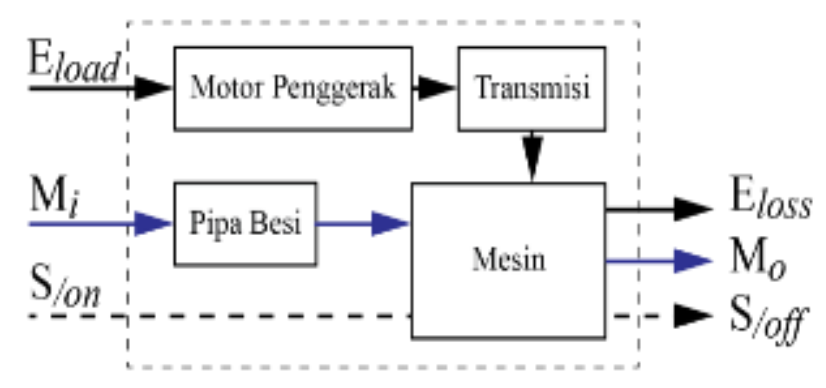

Gambar 3 Sub Struktur fungsi

Keterangan dari sub sturktur fungsi :

$\stackrel{E \longrightarrow}{\longrightarrow}$ :Energi listrik

$\longrightarrow \quad$ : Batas sistem mesin tube notcher

$\stackrel{M}{\longrightarrow}:$ Pipa besi /material

$\stackrel{S \rightarrow}{\longrightarrow}$ : Sinyal pengoperasian mesin

$\square$ : Fungsi utama mesin

Eload : Listrik terhubung

Son : Pengoperasian mesin

Eloss :Listrik terputus

Soff :Pengoperasian mesin selesai

$\mathbf{M}_{\mathbf{i}} \quad$ :Pipa utuh

Mo : Pipa berprofil

Setelah dibuat tabel persyaratan, struktur fungsi dan diagram pohon fungsi maka selanjutnya yang dicari adalah prinsip-prinsip solusi untuk memenuhi sub fungsi tersebut, metode yang digunakan dalam mencari prinsip solusi adalah metode kombinasi, yaitu metode yang mengkobinasikan semua solusi yang ada dalam bentuk matriks. 
Tabel 2 Matriks solusi sub fungsi

(1)

Pemilihan komponen berdasarkan sebagai berikut :

a. Rangka

Material yang kuat, murah, ringan, tahan karat dan mudah diproses.

b. Dudukan motor dan penjepit

Material yang solid, ringan, murah, tahan karat dan mudah diproses.

c. Motor penggerak

Ringan, dimensi sesuai, murah dan kapasitas sesuai.

d. Transmisi

Putaran rendah, minim getaran, minim suara, murah dan tahan lama.

e. Poros pisau

kuat, murah, memiliki standar, tahan karat dan mudah diproses.

f. Bantalan

Sesuai dengan kebutuhan, memilik standar, murah dan tersedia.

g. Pisau

Memiliki kemampuan untuk memproses material pipa besi.

h. Pelindung

Dapat melindungi pengguna, ringan, tahan lama mudah diproses.

Kombinasi Prinsip Solusi

Untuk mendapatkan suatu rangkaian sistem yang menunjang kombinasi tersebut akan dibagi menjadi 3 varian rangkaian sistem mesin yang ditunjukaan pada tabel 3 dibawah yaitu :

Varian 1 :

$$
1,2 ; 2,1 ; 3,2 ; 4,1 ; 5,2 ; 6,1 ; 7,2 ; 8,1 ; 9,3
$$

Varian 2 :

$$
1,3 ; 2,2 ; 3,1 ; 4,2 ; 5,1 ; 6,2 ; 7,3 ; 8,1, ; 9,2
$$

Varian 3 :

$$
1,1 ; 2,2 ; 3,1 ; 4,3 ; 5,1 ; 6,2 ; 7,1 ; 8,2 ; 9,1
$$


Tabel 3 Kombinasi prinsip solusi

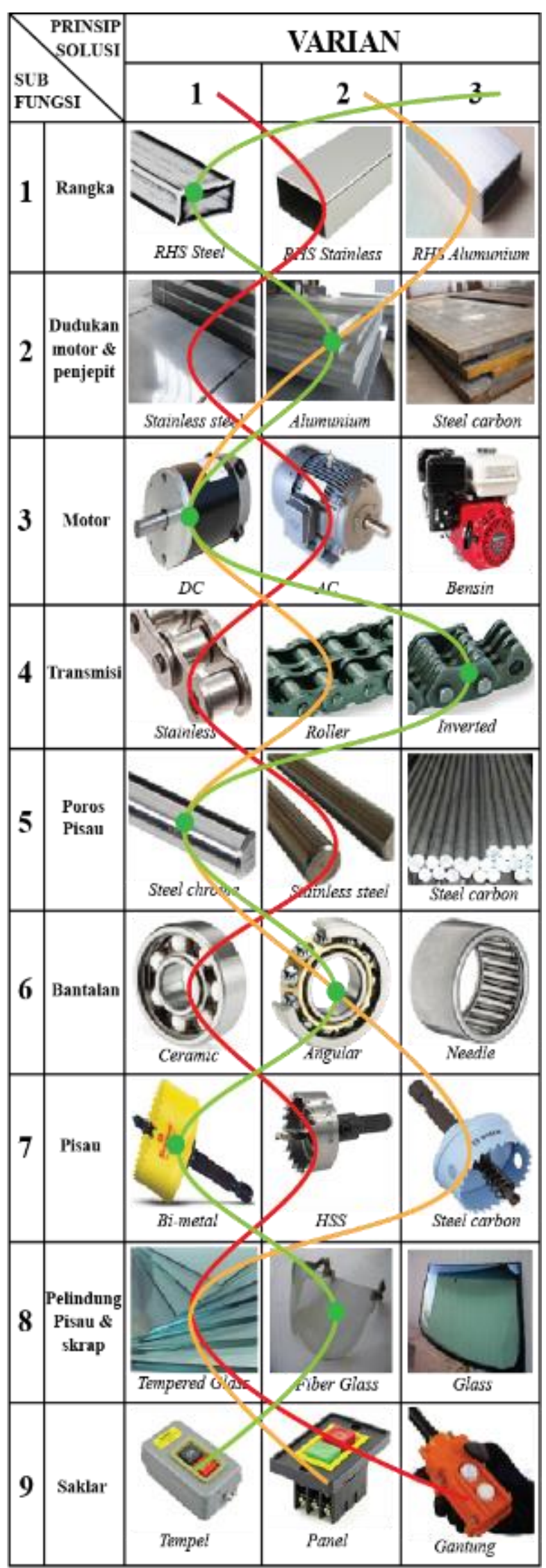

- Kombinasi Var $1=$ Kombinasi Var $2=$ Kombinasi Var 3

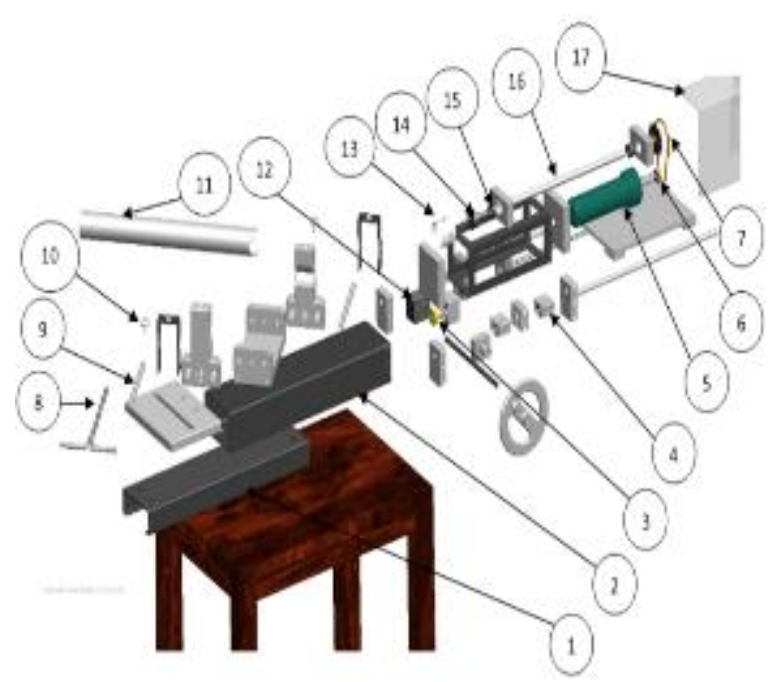

Gambar 4 Komponen yang dibeli

Tabel 4 Spesifikasi Varian Mesin yang dibeli

\begin{tabular}{|c|c|c|c|c|c|}
\hline $\begin{array}{l}\mathbf{N} \\
\mathbf{0}\end{array}$ & Mesin & $\begin{array}{c}\text { Var } \\
1\end{array}$ & Var 2 & Var3 & $\begin{array}{l}\mathbf{Q t} \\
\mathbf{y}\end{array}$ \\
\hline 1 & $\begin{array}{c}\text { Baja } \\
\text { profil C }\end{array}$ & $\begin{array}{c}\text { Baja } \\
\text { karbo } \\
n \\
\end{array}$ & $\begin{array}{c}\text { Baja } \\
\text { karbon }\end{array}$ & $\begin{array}{c}\text { Baja } \\
\text { karbon }\end{array}$ & 1 \\
\hline 2 & RHS & $\begin{array}{c}\text { Baja } \\
\text { karbo } \\
n\end{array}$ & $\begin{array}{c}\text { Baja } \\
\text { karbon }\end{array}$ & $\begin{array}{c}\text { Baja } \\
\text { karbon }\end{array}$ & 1 \\
\hline 3 & $\begin{array}{c}\text { Nut } \\
\text { screw }\end{array}$ & $\begin{array}{c}\text { Kuni } \\
\text { n-gan }\end{array}$ & $\begin{array}{c}\text { Kuning } \\
\text {-an }\end{array}$ & $\underset{n}{\text { kuninga }}$ & 3 \\
\hline 4 & $\begin{array}{l}\text { Linear } \\
\text { slide } \\
\text { box } \\
\end{array}$ & $\begin{array}{c}\text { Alum } \\
\text { uniu } \\
\mathrm{m} \\
\end{array}$ & $\begin{array}{l}\text { Alumu- } \\
\text { nium }\end{array}$ & $\begin{array}{l}\text { Alumu- } \\
\text { nium }\end{array}$ & 4 \\
\hline 5 & $\begin{array}{c}\text { Motor } \\
\text { pengger } \\
\text { ak }\end{array}$ & $\mathrm{AC}$ & $\overline{\mathrm{DC}}$ & $\overline{\mathrm{DC}}$ & 1 \\
\hline 6 & Sproket & $\begin{array}{c}\text { Baja } \\
\text { karbo } \\
n\end{array}$ & $\begin{array}{c}\text { Baja } \\
\text { karbon }\end{array}$ & $\begin{array}{c}\text { Baja } \\
\text { karbon }\end{array}$ & 2 \\
\hline 7 & Rantai & $\begin{array}{c}\text { Baja } \\
\text { karbo } \\
n\end{array}$ & $\begin{array}{c}\text { Baja } \\
\text { karbon }\end{array}$ & $\begin{array}{c}\text { Baja } \\
\text { karbon }\end{array}$ & 1 \\
\hline 8 & $\begin{array}{c}\text { Linear } \\
\text { shaft }\end{array}$ & $\begin{array}{c}\text { Baja } \\
\text { khro } \\
\text { m }\end{array}$ & $\begin{array}{c}\text { Baja } \\
\text { khrom }\end{array}$ & $\begin{array}{c}\text { Baja } \\
\text { khrom }\end{array}$ & 1 \\
\hline 9 & Baut 14 & $\begin{array}{c}\text { Baja } \\
\text { karbo } \\
n \\
\end{array}$ & $\begin{array}{c}\text { Baja } \\
\text { karbon }\end{array}$ & $\begin{array}{c}\text { Baja } \\
\text { karbon }\end{array}$ & 2 \\
\hline 10 & Pipa & $\begin{array}{l}\text { Stain } \\
\text {-less }\end{array}$ & $\begin{array}{c}\text { Stainles } \\
\mathrm{s}\end{array}$ & Stainless & 2 \\
\hline 11 & $\begin{array}{l}\text { Reducti } \\
\text { on screw }\end{array}$ & $\begin{array}{c}\text { Alum } \\
\text { uniu } \\
\mathrm{m}\end{array}$ & $\begin{array}{l}\text { Alumu- } \\
\text { nium }\end{array}$ & $\begin{array}{c}\text { Alumu- } \\
\text { nium }\end{array}$ & 1 \\
\hline 12 & $\begin{array}{c}\text { Hole } \\
\text { saw }\end{array}$ & HSS & $\begin{array}{c}\text { Baja } \\
\text { karbon }\end{array}$ & Bi-metal & 2 \\
\hline 13 & $\begin{array}{l}\text { Adapter } \\
\text { holesaw }\end{array}$ & $\begin{array}{c}\text { Chuc } \\
\mathrm{k}\end{array}$ & Chuck & Chuck & 1 \\
\hline
\end{tabular}




\begin{tabular}{|c|c|c|c|c|l|}
\hline 14 & Bearing & $\begin{array}{c}\text { Baja } \\
\text { karbo } \\
\mathrm{n}\end{array}$ & $\begin{array}{c}\text { Baja } \\
\text { karbon }\end{array}$ & $\begin{array}{c}\text { Baja } \\
\text { karbon }\end{array}$ & 9 \\
\hline 15 & $\begin{array}{c}\text { Tools } \\
\text { shaft }\end{array}$ & $\begin{array}{c}\text { Stain } \\
\text {-less }\end{array}$ & $\begin{array}{c}\text { Baja } \\
\text { karbon }\end{array}$ & $\begin{array}{c}\text { Baja } \\
\text { khrom }\end{array}$ & 1 \\
\hline 16 & Akrilik & $\begin{array}{c}\text { Fiber } \\
- \\
\text { glass }\end{array}$ & $\begin{array}{c}\text { Fiber- } \\
\text { glass }\end{array}$ & $\begin{array}{c}\text { Fiber- } \\
\text { glass }\end{array}$ & 1 \\
\hline
\end{tabular}

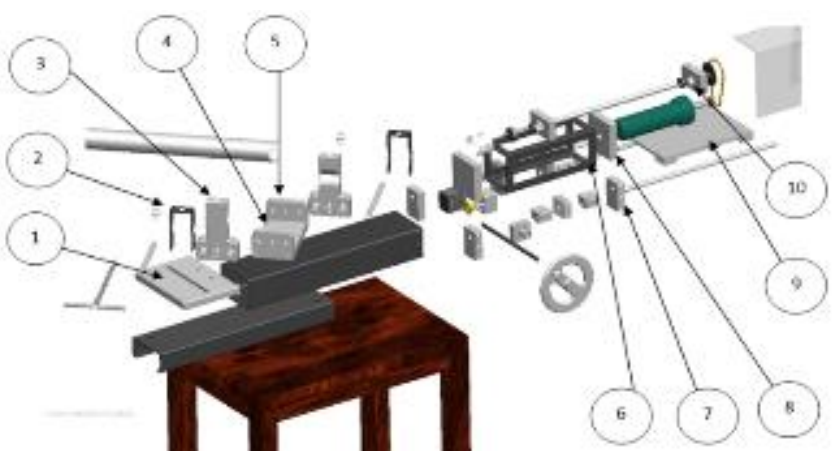

Gambar 5 Spesiikasi Varian Mesin yang dibuat

Tabel 5 Spesifikasi Varian Mesin yang Dibuat

\begin{tabular}{|c|c|c|c|c|c|}
\hline No & Mesin & Var 1 & Var 2 & $\begin{array}{c}\text { Var } \\
3\end{array}$ & Qty \\
\hline 1. & $\begin{array}{l}\text { Vise } \\
\text { support }\end{array}$ & $\begin{array}{l}\text { Stainless } \\
\text { steel }\end{array}$ & $\begin{array}{c}\text { Alum } \\
\text { uniu } \\
m\end{array}$ & $\begin{array}{c}\text { Alum } \\
\text { uniu } \\
m \\
\end{array}$ & 1 \\
\hline 2. & Vise pipe & $\begin{array}{c}\text { Stainless } \\
\text { steel }\end{array}$ & Steel & Steel & 2 \\
\hline 3. & $\begin{array}{l}\text { Vise pipe } \\
\text { (pencekam) }\end{array}$ & $\begin{array}{l}\text { Stainless } \\
\text { steel }\end{array}$ & $\begin{array}{c}\text { Alum } \\
\text { uniu } \\
m\end{array}$ & $\begin{array}{c}\text { Alum } \\
\text { ипiи } \\
m\end{array}$ & 2 \\
\hline 4. & $\begin{array}{l}\text { Dudukan } \\
\text { vise pipe }\end{array}$ & $\begin{array}{l}\text { Stainless } \\
\text { steel }\end{array}$ & $\begin{array}{l}\text { Aluun } \\
\text { ium }\end{array}$ & $\begin{array}{c}\text { Alum } \\
\text { uniu } \\
m\end{array}$ & 1 \\
\hline 5. & Vise pipe & $\begin{array}{c}\text { Stainless } \\
\text { steel }\end{array}$ & $\begin{array}{c}\text { Alum } \\
\text { uniu } \\
m\end{array}$ & $\begin{array}{c}\text { Alum } \\
\text { uniu } \\
m\end{array}$ & 2 \\
\hline 6. & $\begin{array}{l}\text { Motor } \\
\text { frame } \\
\text { hollow }\end{array}$ & $\begin{array}{c}\text { Stainless } \\
\text { steel }\end{array}$ & $\begin{array}{c}\text { Alum } \\
\text { uniu } \\
m \\
\end{array}$ & Steel & 1 \\
\hline 7. & $\begin{array}{l}\text { Braket } \\
\text { shaft }\end{array}$ & $\begin{array}{c}\text { Stainless } \\
\text { steel }\end{array}$ & $\begin{array}{c}\text { Alum } \\
\text { uniu } \\
m \\
\end{array}$ & $\begin{array}{c}\text { Alum } \\
\text { uniu } \\
m\end{array}$ & 6 \\
\hline 8. & $\begin{array}{l}\text { Motor box } \\
\text { bearing }\end{array}$ & $\begin{array}{c}\text { Stainless } \\
\text { steel }\end{array}$ & $\begin{array}{c}\text { Alum } \\
\text { uniu } \\
m\end{array}$ & $\begin{array}{c}\text { Alum } \\
\text { uniu } \\
m\end{array}$ & 2 \\
\hline 9. & $\begin{array}{l}\text { Motor } \\
\text { frame }\end{array}$ & $\begin{array}{c}\text { Stainless } \\
\text { steel }\end{array}$ & $\begin{array}{c}\text { Alum } \\
\text { uniu } \\
m \\
\end{array}$ & $\begin{array}{c}\text { Alum } \\
\text { uniu } \\
m \\
\end{array}$ & 1 \\
\hline 10 & $\begin{array}{l}\text { Shaft tools } \\
\text { bearing } \\
\text { box }\end{array}$ & $\begin{array}{c}\text { Stainless } \\
\text { steel }\end{array}$ & $\begin{array}{c}\text { Alum } \\
\text { uniu } \\
\text { m }\end{array}$ & $\begin{array}{c}\text { Alum } \\
\text { uniu } \\
m\end{array}$ & 2 \\
\hline
\end{tabular}

\section{Selection Chart}

Dengan tabel 6 dibawah, maka varian 2 (V2) dinyatakan tereleminasi karena:

a. Tidak kompatibel

b. Tidak sesuai dengan daftar persyaratan

c. Secara prinsip dapat diwujudkan

d. Dalam biaya produksi

e. Memenuhi syarat keamanan

f. Tidak sesuai keinginan pembuat

g. Informasi tidak mendukung

h. Tidak sesuai karena spesifikasi pada varian 2 tidak mampu memproses material yang akan diproses.

Tabel 6 Selection chart

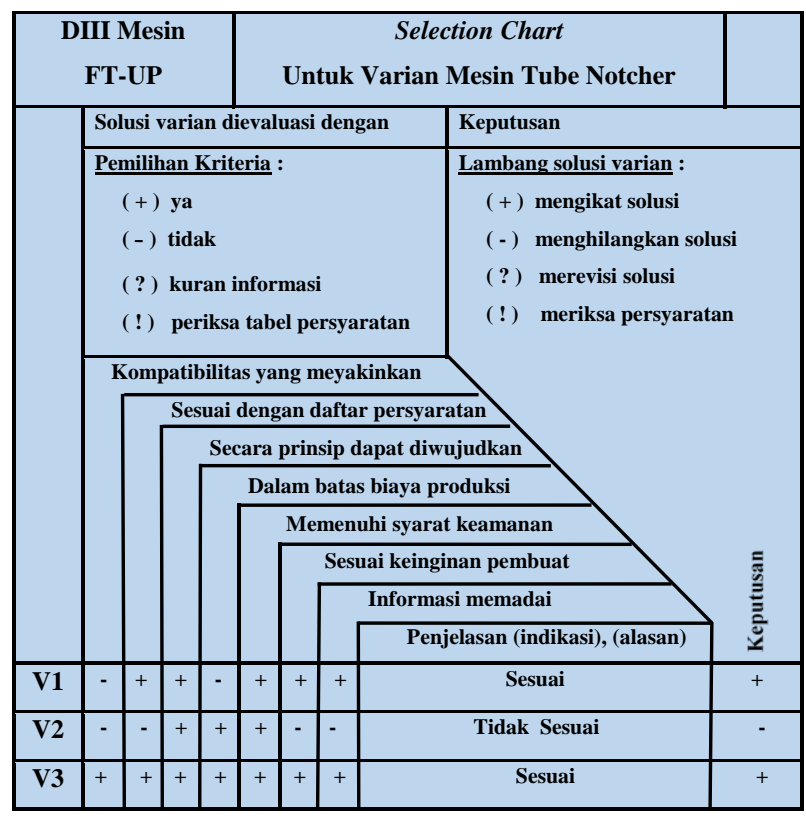




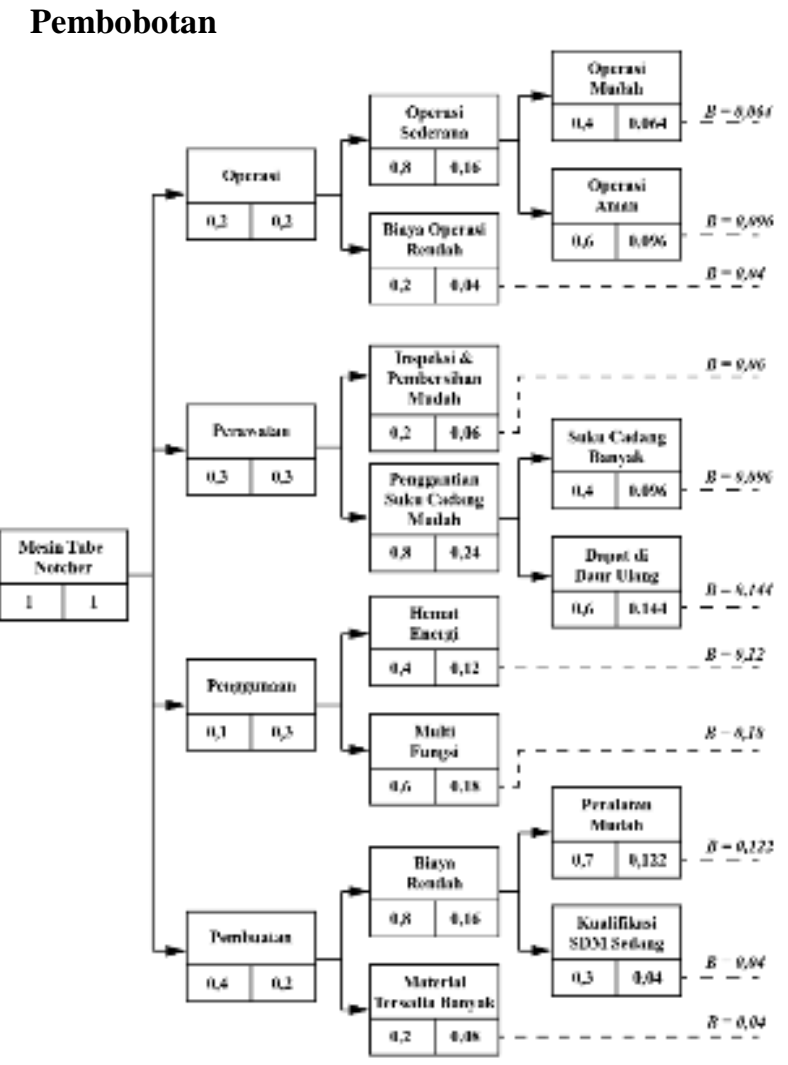

Gambar 6 Diagram pembobotan

Tabel 7 Kriteria evaluasi pembobotan Varian 1

\begin{tabular}{|c|c|c|c|c|c|c|}
\hline \multirow{2}{*}{$\begin{array}{l}\mathbf{N} \\
\mathbf{0}\end{array}$} & \multirow{2}{*}{$\begin{array}{l}\text { Kriteria } \\
\text { Evaluasi }\end{array}$} & \multirow[t]{2}{*}{ B } & \multirow{2}{*}{$\begin{array}{c}\text { Param } \\
\text { eter }\end{array}$} & \multicolumn{3}{|c|}{ Varian 1} \\
\hline & & & & $\mathbf{A}$ & $\mathbf{P}$ & HB \\
\hline 1 & $\begin{array}{l}\text { Operasi } \\
\text { mudah }\end{array}$ & 0,064 & Disain & Bagus & 3 & 0,192 \\
\hline 2 & $\begin{array}{l}\text { Operasi } \\
\text { aman }\end{array}$ & 0,096 & Disain & Ideal & 4 & 0,384 \\
\hline 3 & $\begin{array}{l}\text { Biaya } \\
\text { operasi } \\
\text { rendah }\end{array}$ & 0,04 & Disain & $\begin{array}{l}\text { Ditole } \\
\text {-ransi }\end{array}$ & 1 & 0,04 \\
\hline 4 & $\begin{array}{l}\text { Inspeksi } \\
\text { dan } \\
\text { pembersi } \\
\text { han } \\
\text { mudah }\end{array}$ & 0,06 & Kinerja & Ideal & 4 & 0.24 \\
\hline 5 & $\begin{array}{l}\text { Suku } \\
\text { cadang } \\
\text { banyak }\end{array}$ & 0,096 & Kinerja & Ideal & 4 & 0,384 \\
\hline 6 & $\begin{array}{l}\text { Dapat } \\
\text { didaur } \\
\text { ulang }\end{array}$ & 0,144 & $\begin{array}{l}\text { Konsu } \\
\text { msi } \\
\text { energi }\end{array}$ & $\begin{array}{l}\text { Ditole } \\
\text {-ransi }\end{array}$ & 2 & 0,288 \\
\hline 7 & $\begin{array}{l}\text { Hemat } \\
\text { energi }\end{array}$ & 0,12 & Disain & Ideal & 4 & 0,48 \\
\hline 8 & $\begin{array}{l}\text { Multi } \\
\text { fungsi }\end{array}$ & 0,18 & Waktu & $\begin{array}{l}\text { Ditole } \\
\text {-ransi }\end{array}$ & 2 & 0,36 \\
\hline 9 & $\begin{array}{l}\text { Peralatan } \\
\text { tersedia }\end{array}$ & 0,122 & $\begin{array}{l}\text { Waktu } \\
\text { dan } \\
\text { biaya }\end{array}$ & Ideal & 4 & 0,488 \\
\hline
\end{tabular}

\begin{tabular}{|c|l|l|l|l|l|l|}
\hline 10 & $\begin{array}{l}\text { Kualifika } \\
\text { si SDM }\end{array}$ & 0,048 & $\begin{array}{l}\text { Faktor } \\
\text { ketaha } \\
\text { nan }\end{array}$ & Ideal & 4 & 0,192 \\
\hline 11 & $\begin{array}{l}\text { Keterse } \\
\text { diaan } \\
\text { material }\end{array}$ & 0,04 & Waktu & $\begin{array}{l}\text { Mem- } \\
\text { adai }\end{array}$ & 3 & 0,12 \\
\hline \multicolumn{3}{|c|}{ Jumlah hasil bobot $(H B)$} & $\mathbf{3 , 1 6 8}$ \\
\hline
\end{tabular}

Tabel 8Kriteria evaluasi pembobotan Varian 3

\begin{tabular}{|c|c|c|c|c|c|c|}
\hline \multirow{2}{*}{$\begin{array}{l}\mathbf{N} \\
\mathbf{0}\end{array}$} & \multirow{2}{*}{$\begin{array}{l}\text { Kriteria } \\
\text { Evaluasi }\end{array}$} & \multirow[t]{2}{*}{ B } & \multirow{2}{*}{$\begin{array}{c}\text { Param } \\
\text { eter }\end{array}$} & \multicolumn{3}{|c|}{ Varian 3} \\
\hline & & & & $\mathbf{A}$ & $\mathbf{P}$ & HB \\
\hline 1 & $\begin{array}{l}\text { Operasi } \\
\text { mudah }\end{array}$ & 0,064 & Disain & Ideal & 4 & 0,256 \\
\hline 2 & $\begin{array}{l}\text { Operasi } \\
\text { aman }\end{array}$ & 0,096 & Disain & $\begin{array}{l}\text { Bagu } \\
\text { S }\end{array}$ & 3 & 0,288 \\
\hline 3 & $\begin{array}{l}\text { Biaya } \\
\text { operasi } \\
\text { rendah }\end{array}$ & 0,04 & Disain & Ideal & 4 & 0,16 \\
\hline 4 & $\begin{array}{l}\text { Inspeksi } \\
\text { dan } \\
\text { pembersi } \\
\text { han } \\
\text { mudah }\end{array}$ & 0,06 & Kinerja & Ideal & 4 & 0,24 \\
\hline 5 & $\begin{array}{l}\text { Suku } \\
\text { cadang } \\
\text { banyak }\end{array}$ & 0,096 & Kinerja & $\begin{array}{l}\text { Bagu } \\
\text { s }\end{array}$ & 3 & 0,288 \\
\hline 6 & $\begin{array}{l}\text { Dapat } \\
\text { didaur } \\
\text { ulang }\end{array}$ & 0,144 & $\begin{array}{l}\text { Konsu } \\
\text { msi } \\
\text { energi }\end{array}$ & Ideal & 4 & 0,576 \\
\hline 7 & $\begin{array}{l}\text { Hemat } \\
\text { energi }\end{array}$ & 0,12 & Disain & Ideal & 4 & 0,48 \\
\hline 8 & $\begin{array}{l}\text { Multi } \\
\text { fungsi }\end{array}$ & 0,18 & Waktu & $\begin{array}{l}\text { Bagu } \\
\text { s }\end{array}$ & 3 & 0,54 \\
\hline 9 & $\begin{array}{l}\text { Peralatan } \\
\mathrm{n} \text { tersedia }\end{array}$ & 0,122 & $\begin{array}{l}\text { Waktu } \\
\text { dan } \\
\text { biaya }\end{array}$ & Ideal & 4 & 0,488 \\
\hline 10 & $\begin{array}{l}\text { Kualifika } \\
\text { si SDM }\end{array}$ & 0,048 & $\begin{array}{l}\text { Faktor } \\
\text { ketahan } \\
\text { an }\end{array}$ & $\begin{array}{l}\text { Bagu } \\
\text { s }\end{array}$ & 3 & 0,144 \\
\hline 11 & $\begin{array}{l}\text { Ketersedi } \\
\text { aan } \\
\text { material }\end{array}$ & 0,04 & Waktu & $\begin{array}{l}\text { Bagu } \\
\text { s }\end{array}$ & 3 & 0,12 \\
\hline \multicolumn{6}{|c|}{ Jumlah hasil bobot (HB) } & 3,580 \\
\hline
\end{tabular}

Keterangan kriteria evaluasi :

B : Bobot

$\boldsymbol{P}$ : Poin analisis

$\boldsymbol{H B}$ : Hasil pembobotan

$\boldsymbol{A}$ : Arti analisis

$$
\begin{aligned}
& \operatorname{Varian} 1 \rightarrow W R J=\frac{3,168}{3 \times 12}=0,088 \\
& V \text { arian } 3 \rightarrow W R J=\frac{3,580}{3 \times 12}=0,144
\end{aligned}
$$


Tabel 9 Skala nilai

\begin{tabular}{|c|c|c|c|}
\hline \multicolumn{4}{|c|}{ Value Scale } \\
\hline \multicolumn{2}{|c|}{ Use value analysis } & \multicolumn{2}{|c|}{ Guideline VDI 2225} \\
\hline $\begin{array}{c}\text { Point } \\
\text { s }\end{array}$ & Meaning & $\begin{array}{c}\text { Point } \\
\text { s }\end{array}$ & Meaning \\
\hline 0 & $\begin{array}{c}\text { Solusi sangat tidak } \\
\text { berguna }\end{array}$ & \multirow[t]{2}{*}{0} & \multirow[t]{2}{*}{$\begin{array}{c}\text { Tidak } \\
\text { memuaskan }\end{array}$} \\
\hline 1 & $\begin{array}{c}\text { Solusi sangat tidak } \\
\text { memadai }\end{array}$ & & \\
\hline 2 & Solusi lemah & \multirow[t]{2}{*}{1} & \multirow[t]{2}{*}{ Ditoleransi } \\
\hline 3 & Solusi lumayan & & \\
\hline 4 & Solusi memadai & \multirow[t]{2}{*}{2} & \multirow[t]{2}{*}{ Memadai } \\
\hline 5 & Solusi Memuaskan & & \\
\hline 6 & $\begin{array}{l}\text { Solusi bagus } \\
\text { dengan sedikit } \\
\text { kekurangan }\end{array}$ & \multirow[t]{2}{*}{3} & \multirow[t]{2}{*}{ Bagus } \\
\hline 7 & Solusi bagus & & \\
\hline 8 & Solusi sangat bagus & \multirow[t]{3}{*}{4} & \multirow{3}{*}{$\begin{array}{c}\text { Sangat } \\
\text { bagus/ideal }\end{array}$} \\
\hline 9 & $\begin{array}{c}\text { Solusi melebihi } \\
\text { persyaratan }\end{array}$ & & \\
\hline 10 & Solusi ideal & & \\
\hline
\end{tabular}

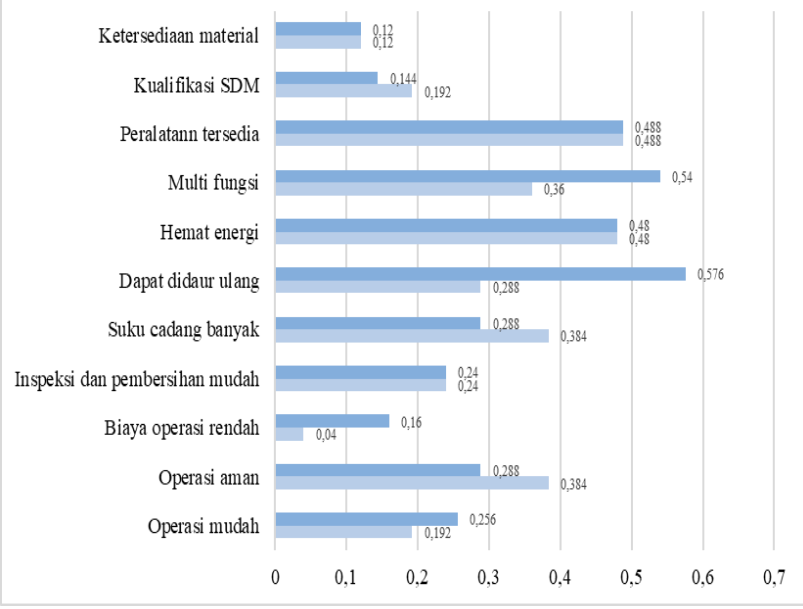

Gambar 7 Diagram pembobotan

Berdasarkan pembobotan varian 3 memiliki peringkat lebih tinggi daripada varian1 maka yang terpilih yaitu varian 3

\section{Perhitungan Perancangan}

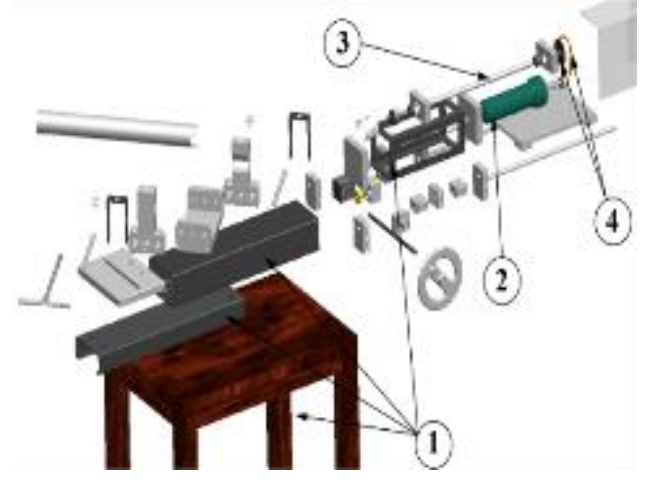

Gambar 8 Analisis Perancangan Mesin tube notcher

Menganalisis perancangan menggunakan perhitungan :

1. Berat total pada kontruksi rangka

2. Perhitungan daya rencana
a. Spindel speed $(n)$
b. Cutting speed $\left(V_{c}\right)$
c. Penetration rate $\left(V_{f}\right)$
d. Feed per revolution $\left(f_{n}\right)$
e. Metal removal rate $(Q)$
f. Net power requirement $\left(P_{c}\right)$

3. Perhitungan poros

4. Perhitungan sproket dan rantai

\section{Berat total pada konstruksi rangka}

Tabel 10 Daftar Berat Komponen Mesin Tube Notcher

\begin{tabular}{|c|c|c|c|c|}
\hline No. & $\begin{array}{c}\text { Nama } \\
\text { komponen }\end{array}$ & $\begin{array}{l}\text { Berat } \\
(\mathbf{k g} \\
\left./ \mathrm{mm}^{3}\right)\end{array}$ & Qty & $\begin{array}{c}\begin{array}{c}\text { Berat } \\
\text { total } \\
(\mathrm{kg}\end{array} \\
\left./ \mathrm{mm}^{3}\right)\end{array}$ \\
\hline 1 & Braket shaft & 0,085 & 6 & 0,51 \\
\hline 2 & Linear shaft & 0,390 & 2 & 0,78 \\
\hline 3 & Bearing & 0,045 & 13 & 0,585 \\
\hline 4 & Lead screw & 0,16 & 2 & 0,32 \\
\hline 5 & $\begin{array}{l}\text { Reduction } \\
\text { screw }\end{array}$ & 0,233 & 1 & 0,233 \\
\hline 6 & Shaft steer & 0,154 & 1 & 0,154 \\
\hline 7 & Steering & 0,953 & 1 & 0,953 \\
\hline 8 & Vise support & 0,924 & 1 & 0,924 \\
\hline 9 & Motor frame & 1,479 & 1 & 1,479 \\
\hline 10 & $\begin{array}{l}\text { Motor frame } \\
\text { hollow }\end{array}$ & 2,342 & 1 & 2,342 \\
\hline 11 & $\begin{array}{l}\text { Motor box } \\
\text { bearing }\end{array}$ & 0,477 & 2 & 0,477 \\
\hline 12 & $\begin{array}{l}\text { Motor } \\
\text { penggerak dc }\end{array}$ & 1,4 & 1 & 1,4 \\
\hline 13 & Rantai & 0,043 & 1 & 0,043 \\
\hline 14 & Sproket & 0,080 & 2 & 0,16 \\
\hline 15 & $\begin{array}{l}\text { Shaft tools } \\
\text { bearing box }\end{array}$ & 0,077 & 2 & 0,154 \\
\hline 16 & Tools shaft & 0,216 & 1 & 0,216 \\
\hline 17 & $\begin{array}{l}\text { Kepala bor / } \\
\text { chuck }\end{array}$ & 0,540 & 1 & 0,540 \\
\hline 18 & $\begin{array}{l}\text { Adapter hole } \\
\text { saw }\end{array}$ & 0,589 & 1 & 0,589 \\
\hline 19 & Hole saw & 0,181 & 1 & 0,362 \\
\hline
\end{tabular}




\begin{tabular}{|c|c|c|c|c|}
\hline 20 & $\begin{array}{l}\text { Shaft tools } \\
\text { cover }\end{array}$ & 0,140 & 1 & 0,140 \\
\hline 21 & Vise pipe & 0,10 & 2 & 0,2 \\
\hline 22 & $\begin{array}{l}\text { Dudukan vise } \\
\text { pipe }\end{array}$ & 1,566 & 1 & 1,566 \\
\hline 23 & $\begin{array}{l}\text { Vise pipe } \\
\text { (pencekam) }\end{array}$ & 0,924 & 2 & 1,848 \\
\hline 24 & Vise tools & 0,902 & 2 & 1,804 \\
\hline 25 & $\begin{array}{l}\text { Libear shaft } \\
12 \mathrm{~mm}\end{array}$ & 0,14 & 2 & 0,28 \\
\hline 26 & $\begin{array}{l}\text { Shaft vise } 10 \\
\mathrm{~mm}\end{array}$ & 0,154 & 1 & 0,154 \\
\hline 27 & Nut screw & 0,117 & 3 & 0,351 \\
\hline 28 & $\begin{array}{l}\text { Besi hollow } \\
\text { persegi }\end{array}$ & 3 & 1 & 3 \\
\hline 29 & Pipa material & 0,623 & 1 & 0,623 \\
\hline \multicolumn{4}{|c|}{ Jumlah Berat total } & 22,187 \\
\hline
\end{tabular}

\section{Perhitungan daya rencana}

Daya motor [4] dapat dihitung berdasarkan beberapa hal, yaitu :

a. Spindel speed $(n)$

Spindel speed adalah kecepatan poros transmisi yang menggerakan pisau.

Tabel 11 Kecepatan Hole Saw[3]

\begin{tabular}{|c|c|c|c|c|c|c|c|c|c|}
\hline \multirow{3}{*}{$\begin{array}{c}\text { Ukuran } \\
\text { Pipa }\end{array}$} & \multirow{3}{*}{$\begin{array}{c}\text { Stainless } \\
\text { Steel, } \\
\text { rpm }\end{array}$} & \multirow{3}{*}{$\begin{array}{r}\text { Steel, } \\
\text { rpm }\end{array}$} & \multirow{3}{*}{$\begin{array}{c}\text { Almuniu } \\
\text { m, rpm }\end{array}$} & \multirow{3}{*}{$\begin{array}{c}\text { Wood, } \\
\text { PVC, } \\
\text { rpm }\end{array}$} & \multirow{4}{*}{$\begin{array}{c}\text { Material } \\
\text { benda } \\
\text { kerja }\end{array}$} & \multirow{4}{*}{$\begin{array}{c}\text { Kekuatan } \\
\text { tarik } \\
\text { Kg.mm² }\end{array}$} & \multirow{2}{*}{\multicolumn{3}{|c|}{$\begin{array}{l}\text { Gaya potong spesifik } \\
\mathrm{N} / \mathrm{mm}^{2}\end{array}$}} \\
\hline & & & & & & & & & \\
\hline & & & & & & & $\begin{array}{c}0,1 \mathrm{~mm} / \\
\text { rev }\end{array}$ & $\begin{array}{c}0,2 \mathrm{~mm} / \\
\text { rev }\end{array}$ & $\begin{array}{c}0,3 \mathrm{~mm} / \\
\text { rev }\end{array}$ \\
\hline \multirow[t]{2}{*}{$1 "$} & \multirow[t]{2}{*}{175} & \multirow[t]{2}{*}{350} & \multirow[t]{2}{*}{525} & \multirow[t]{2}{*}{2700} & & & \multirow{3}{*}{2200} & \multirow{3}{*}{1950} & \multirow{3}{*}{1820} \\
\hline & & & & & \multirow{2}{*}{$\begin{array}{l}\text { Mild } \\
\text { steel }\end{array}$} & \multirow[t]{2}{*}{520} & & & \\
\hline $2 "$ & 85 & 170 & 255 & 2000 & & & & & \\
\hline $3 "$ & 55 & 155 & 170 & 1800 & $\begin{array}{c}\text { Medium } \\
\text { steel }\end{array}$ & 620 & 1980 & 1800 & 1730 \\
\hline $3,5^{\prime \prime}$ & 45 & 95 & 170 & 1800 & $\begin{array}{c}\text { Hard } \\
\text { steel }\end{array}$ & 720 & 2520 & 2200 & 2040 \\
\hline Tips & $\begin{array}{c}\text { Cutting } \\
\text { oil }\end{array}$ & $\begin{array}{l}\text { Cutting } \\
\text { oil }\end{array}$ & Cutting oil & - & $\begin{array}{l}\text { Tool } \\
\text { steel }\end{array}$ & 670 & 1980 & 1800 & 1730 \\
\hline & & & & & $\begin{array}{c}\text { Stainless } \\
\text { steel }\end{array}$ & 770 & 2030 & 1800 & 1750 \\
\hline
\end{tabular}

b. Cutting speed $\left(V_{c}\right)$

Cutting speed atau kecepatan potong berdasarkan diameter benda kerja dan kecepatan poros yang digerakan.

$$
V_{c} \rightarrow \frac{89 \times 3,14 \times 45}{1000}=12,5757 \mathrm{~mm} / \mathrm{min}
$$

Dimana :

$$
n=45 \mathrm{rpm}
$$

$$
D_{C}=89 \mathrm{~mm}
$$

c. Penetration rate $\left(V_{f}\right)$

Penetration rate berdasarkan ketebalan benda kerja, pada pipa stainless steel diameter $89 \mathrm{~mm}$ dengan ketebalan 1,2 $\mathrm{mm}$. Jadi apabila ingin menembus pipa tersebut harus melewati 2 permukaan pipa, yaitu permukaan luar dan permukaan dalam, maka :

$$
V_{f} \rightarrow 2 \times 1,2=2,4 \mathrm{~mm}
$$

d. Feed per revolution $\left(f_{n}\right)$
Feed per revolution adalah pemakanan pisau pada benda kerja berdasarkan putaran pisau.

Dimana :

$$
f_{n} \rightarrow \frac{V_{f}}{n}=m / r e v
$$

$$
\begin{aligned}
& V_{f}=2,4 \mathrm{~mm} \\
& n=45 \mathrm{rpm}
\end{aligned}
$$

$$
f_{n} \rightarrow \frac{2,4}{45}=0,053 \mathrm{~mm} / \mathrm{rev}
$$

e. Metal removal rate $(Q)$

Tingkat pengikisan benda kerja terhadap waktu.

Dimana :

$$
Q \rightarrow \frac{D_{C} \times f_{n} \times V_{C}}{4}=\mathrm{mm}^{3} / \mathrm{min}
$$

$$
\begin{aligned}
& V_{f}=2,4 \mathrm{~mm} \\
& V_{C}=12,5757 \mathrm{~mm} \\
& n=45 \mathrm{rpm} \\
& Q \rightarrow \frac{89 \times 0,053 \times 12,5757}{4} \\
& \quad=14,82989423 \mathrm{~mm}^{3} / \mathrm{min}
\end{aligned}
$$

f. Net power requirement $\left(P_{c}\right)$

Nilai daya sesuai kebutuhan berdasarkan data spesifik gaya potong benda yang akan dikerjakan.

Tabel 12 Gaya potong spesifik

$$
\begin{gathered}
P_{c} \rightarrow \frac{f_{n} \times V_{C} \times D_{C} \times K_{C}}{240 \times 10^{3}}=k w \\
\text { Dimana : } \\
V_{f}=2,4 \mathrm{~mm} \\
V_{C}=12,5757 \mathrm{~mm} \\
n=45 \mathrm{rpm} \\
K_{C}=2030 \mathrm{~N} / \mathrm{mm}^{2} \\
P_{c} \rightarrow \frac{0,053 \times 12,5757 \times 89 \times 2030}{240 \times 10^{3}} \\
=0,5017447546 \mathrm{kw}
\end{gathered}
$$

\section{Perhitungan poros dan beban puntir[2]}

Spesifikasi poros berdasarkan varian terpilih SC222

a. Daya rencana $\left(P_{d}\right)$

Untuk mampu memberikan dayatambahan, sepertisaat memulai menyalakan mesin diperlukan daya yang lebih 
besar tentunya, dengan demikian diperlukan faktor koreksi daya yang ditransmisikan.

Tabel 13 Faktor koreksi perencanaan poros[2]

\begin{tabular}{|l|c|}
\hline \multicolumn{1}{|c|}{ Daya yang akan ditransmisikan } & $\boldsymbol{f}_{\boldsymbol{c}}$ \\
\hline Daya rata-rata yang diperlukan & $1,2<2,0$ \\
\hline Daya maksimum yang diperlukan & $0,8<1,2$ \\
\hline Daya normal & $1,0<1,5$ \\
\hline
\end{tabular}

$P_{d} \rightarrow F_{C} \times P=k w$

$$
\begin{array}{cc}
\text { Dimana : } & F_{C}=0,8 \mathrm{~mm} \\
& P=0,501 \mathrm{rpm} \\
P_{d} \rightarrow 1,2 \times 0,501=0,6012 \mathrm{kw}
\end{array}
$$

Maka besar daya motor dengan faktor koreksi sebesar $\rightarrow$ $0,6012 \mathrm{kw}$

\section{b. Momenrencana $(T)$}

Menentukan momen pada poros penggerak dan poros yang digerakan berdasarkan daya motor per putaran putaran poros penggerak dan putaran poros yang digerakan.

$$
\begin{aligned}
& T \rightarrow 9,75 \times 10^{5} \times \frac{P_{d}}{n}=k g . m m \\
& \text { Dimana : } \quad P_{d}=0,6012 \mathrm{kw} \\
& n_{1}=340 \mathrm{rpm} \\
& n_{2}=680 \mathrm{rpm} \\
& T_{1} \rightarrow 9,75 \times 10^{5} \times \frac{0,6012}{340}=1.724,029 \mathrm{~kg} . \mathrm{mm}
\end{aligned}
$$

Momen puntir rancana yang terjadi pada poros penggerak $\rightarrow 1.724,029 \mathrm{~kg} . \mathrm{mm}$

$$
T_{2} \rightarrow 9,75 \times 10^{5} \times \frac{0,6012}{680}=862,014 \mathrm{~kg} \cdot \mathrm{mm}
$$

Momen rancana yang terjadi pada poros yang digerakan $\rightarrow 862,014 \mathrm{~kg} . \mathrm{mm}$

c. Tegangan Geser $\left(T_{g}\right)$

Apabila momen puntir dibebankan pada suatu diameter poros maka akan terjadi tegangan geser.

Tabel 14 Faktor keamanan tegangan geser

\begin{tabular}{|l|c|}
\hline \multicolumn{1}{|c|}{ Faktor keamanan $\boldsymbol{T}_{\boldsymbol{g}}$} & Harga \\
\hline $\begin{array}{l}\text { Batas kelelahan } \\
\text { puntir } S_{f 1}\end{array}$ & $\begin{array}{c}5,6 \text { untuk bahan SF dan } 6,0 \\
\text { untuk bahanS-C }\end{array}$ \\
\hline $\begin{array}{l}\text { Pengaruh konsentrasi } \\
\text { tegangan } S_{f 2}\end{array}$ & $1,3<3,0$ \\
\hline
\end{tabular}

Dimana :

$$
T_{g} \rightarrow \frac{\sigma b}{S f_{1} \times S f_{2}}=\mathrm{kg} / \mathrm{mm}^{2}
$$

$$
\begin{aligned}
& S f_{1}=6 \\
& S f_{2}=2 \\
& \sigma_{b}=55 \mathrm{~kg} / \mathrm{mm}^{2}(\mathrm{~S} 40 \mathrm{C})
\end{aligned}
$$

$$
T_{g} \rightarrow \frac{55}{6 \times 2}=4,853 \mathrm{~kg} / \mathrm{mm}^{2}
$$

d. Poros rencana sproket $\left(D_{s}\right)$

Menentukan diameter poros penggerak dan diameter poros yang digerakan, dan diperlukan untuk menggunakan faktor koreksi terhadap beban kejutan dan tumbukan, selanjutnya menggunakan faktor keamanan beban lentur.

Tabel 15 Faktor koreksi poros sproket

\begin{tabular}{|l|c|}
\hline \multicolumn{1}{|c|}{ Faktor koreksi $\boldsymbol{d}_{\boldsymbol{s}}$} & Harga \\
\hline $\begin{array}{l}\text { Beban dikenakan secara halus } \\
\left(K_{t}\right)\end{array}$ & 1,0 \\
\hline $\begin{array}{l}\text { Beban dikenakan secara halus } \\
\text { dan sedikit kejutan }\left(K_{t}\right)\end{array}$ & $1,0<1,5$ \\
\hline $\begin{array}{l}\text { Terjadi kenjutan dan tumbukan } \\
\left(K_{t}\right)\end{array}$ & $1,5<3,0$ \\
\hline $\begin{array}{l}\text { Terjadi pembebanan lentur } \\
\left(C_{b}\right)\end{array}$ & $1,2<2,3$ \\
\hline $\begin{array}{l}\text { Tidak terjadi pembebanan lentur } \\
\left(C_{b}\right)\end{array}$ & 1,0 \\
\hline
\end{tabular}

$$
d_{s} \rightarrow\left[\left(\frac{5,1}{T_{g}}\right) K_{t} \times C_{b} \times T\right]^{\frac{1}{3}}=m m
$$

Dimana : $\quad K_{t}=1,0$

$$
C_{b}=1,2
$$

$$
T_{g}=4,853 \mathrm{~kg} / \mathrm{mm}^{2}
$$

$$
\begin{aligned}
T_{1}= & 293,085 \mathrm{~kg} \cdot \mathrm{mm} \\
& T_{2}=2930,850 \mathrm{~kg} \cdot \mathrm{mm}
\end{aligned}
$$

$$
\begin{aligned}
& d_{s 1} \rightarrow\left[\left(\frac{5,1}{4,853}\right) 1,5 \times 1,2 \times 293,085\right]^{\frac{1}{3}} \\
& =8,21 \mathrm{~mm}
\end{aligned}
$$

Maka diameter poros penggerak sebesar $\rightarrow 9 \mathrm{~mm}$

$$
\begin{aligned}
& d_{s 1} \rightarrow\left[\left(\frac{5,1}{4,853}\right) 1,5 \times 1,2 \times 2930,850\right]^{\frac{1}{3}} \\
& =17,69 \mathrm{~mm}
\end{aligned}
$$

Maka diameter poros yang digerakan sebesar $\rightarrow 18 \mathrm{~mm}$

Tabel 16 Daftar diameter poros

\begin{tabular}{|c|c|c|c|c|}
\hline \multicolumn{5}{|c|}{ Diameter poros (mm) } \\
\hline 4 & 10 & 14 & 20 & 30 \\
\hline 4,5 & 11 & 15 & 22 & 31,5 \\
\hline 5 & 11,2 & 16 & 22,4 & 32 \\
\hline 5,6 & 12 & 17 & 24 & 35 \\
\hline 6 & 12,5 & 18 & 25 & 35,5 \\
\hline 6,3 & 14 & 19 & 28 & 38 \\
\hline
\end{tabular}

\section{Perhitungan sproket dan rantai}


Spesifikasi sproket dan rantai:

1. Set condition require in design work

a. Type of machin:

Machine tools atau mesin perkakas

b. Transmission power:

$$
P_{t} \rightarrow 0,6 \mathrm{kw}
$$

c. Running hours in a single day:

3 hours/day atau 3jam/hari

d. Small sprockets speed:

e. Ratio speed: $S R \rightarrow 1 / 2$

$$
d_{p} \rightarrow 340 \mathrm{rpm}
$$

f. Interim center distance.

$$
C \rightarrow 75 \mathrm{~mm}
$$

g. Special uses and enviromental: condition

\section{Pemilihan jenis rantai}

Penulis memilih rantai berjenis rantai gigi atau inverted tooth chain SCR0404 dengan spesifikasi sebagai berikut:

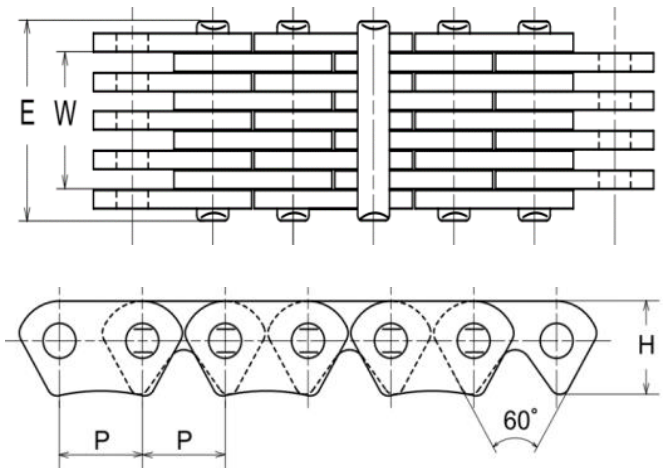

Gambar 9 Analisis perancangan mesin tube notcher

Dimana : $p=6,35 \mathrm{~mm}$

$$
\begin{aligned}
& \text { Jumlah plat }=2 \times 3 \\
& W=3,20 \mathrm{~mm} \\
& E=6 \mathrm{~mm} \\
& H=6,85 \mathrm{~mm} \\
& \text { Kekuatan tarik }=6,85 \mathrm{kN} \text { dengan } 705 \mathrm{kgf} \\
& \text { Berat }=0,172 \mathrm{~kg} / \mathrm{m}
\end{aligned}
$$

1. Perbandingan putaran

Maka berdasarkan spesifikasi diatas penulis menginkanjumlah gigi pada sproket kecil $\left(Z_{1}\right)$ sebanyak 17 dengan perbandingan kecepatan 1:2.

$$
\begin{array}{ll} 
& \frac{1}{2} \times \frac{17}{Z_{2}}=34 \\
\text { Dimana : } \quad & Z_{1}=17
\end{array}
$$

$$
i=\frac{1}{2}
$$

Maka jumlah gigi pada sproket besar $\left(Z_{2}\right)=$ 34

2. Diameter luar sproket $\left(D_{p, d_{p}}\right)$

$$
d_{p}=\frac{6,35}{\sin \left(\frac{180^{\circ}}{17}\right)}=34,5 \mathrm{~mm}
$$

$$
D_{p}=\frac{6,35}{\sin \left(\frac{180^{\circ}}{34}\right)}=68,8 \mathrm{~mm}
$$

Dimana :

$$
\begin{aligned}
& p=6,35 \mathrm{~mm} \\
& Z_{1}=17 \mathrm{gigi} \\
& z_{2}=34 \mathrm{gigi}
\end{aligned}
$$

Maka diameter luar sproket kecil adalah $34,5 \mathrm{~mm}$ dan diameter sproket besar $68,9 \mathrm{~mm}$.

1. Kecepatan rantai $(v)$

Dimana : $p=6,35 \mathrm{~mm}$

$$
v=\frac{17 \times 6,35 \times 680}{1000 \times 60}=1,2 \mathrm{~m} / \mathrm{s}
$$

$$
\begin{aligned}
& Z_{1}=17 \mathrm{gigi} \\
& n_{1}=680 \mathrm{rpm}
\end{aligned}
$$

2. Beban rencana $\left(F_{d}\right)$

$$
F_{d}=\frac{75 \times 0,6012}{1,2}=37,575 \mathrm{~kg}
$$

Dimana : $P=0,6012 \mathrm{~kW}$

$$
\begin{aligned}
& c=75 \mathrm{~mm} \\
& v=1,2 \mathrm{~m} / \mathrm{s}
\end{aligned}
$$

3. Panjang rantai dalam jarak bagi $(L p)$

$$
\begin{aligned}
L_{p}=\frac{17+34}{2}+ & 2 \times \frac{75}{6,35}+\frac{[(17-34) / 6,28]^{2}}{75 / 6,35} \\
= & 49,742 \rightarrow 58 \mathrm{~mm}
\end{aligned}
$$

Dimana : $p=6,35 \mathrm{~mm}$

$$
\begin{aligned}
& Z_{1}=17 \text { gigi } \\
& Z_{2}=34 \text { gigi } \\
& c=75 \mathrm{~mm} \\
& 2 \pi=6,28
\end{aligned}
$$

4. Jarak sumbu poros $\left(C_{p}\right)$

$$
\begin{aligned}
& C_{p} \\
& =\frac{1}{4}\left\{\left(58-\frac{17+34}{2}\right)\right. \\
& +\sqrt{\left.\left(58-\frac{17+34}{2}\right)^{2}-\frac{2}{9,86}(17-34)^{2}\right\}} \\
& =39,7 \rightarrow 40 \\
& \frac{58-17}{34-\frac{17}{39}=2,4 \rightarrow K=6,35}=1,00002 \\
& C=\frac{3,7-3,3 m m}{1,00002}=33,5
\end{aligned}
$$

$$
\begin{aligned}
& \text { Dimana : } \\
& L_{p}=58 \mathrm{~mm} \\
& Z_{1}=17 \mathrm{gigi} \\
& Z_{2}=34 \mathrm{gigi} \\
& \pi^{2}=9,86 \\
& K=1,00002
\end{aligned}
$$

Perincian dari hasil perhitungan di atas adalah:

a. Berat total mesin yaitu $22,187 \mathrm{~kg}$ 
b. Kecepatan poros untuk memotong stainless steel 2inch yaitu $85 \mathrm{rpm}$

c. Kecepatan potong mesin ini adalah $12,5757 \mathrm{~mm} / \mathrm{min}$

d. Kedalaman penetrasi yaitu $2,4 \mathrm{~mm}$

e. Pemakanan material perputaran $0,053 \mathrm{~mm} / \mathrm{rev}$

f. Pengikisan terhadap waktu $14,82989423 \mathrm{~mm}^{3} / \mathrm{min}$

g. Daya berdasarkan gaya potong yaitu $0,5 \mathrm{~kW}$

h. Poros penggerak sebesar $9 \mathrm{~mm}$

i. Poros yang digerakan sebesar $18 \mathrm{~mm}$

\section{KESIMPULAN DAN SARAN}

Berdasarkan hasil perancangan mesin tube notcher ini, penulis dapat menyimpulkan sebagai berikut :

1. Maka varian konsep yang terpilih adalah varian 3 karena :

a. Ketersediaan material yang memadai dipasar

b. Kualifikasi SDM yang sedang pada pengoperasian

c. Peralatan tersedia dipasaran

d. Multifungsi

e. Hemat energi

f. Dapat didaur ulang atau diperbaiki

g. Suku cadang banyak tersedia dipasar

h. Inspeksi dan pembersihan mudah

i. Biaya operasi rendah

j. Operasi aman bagi pengguna

2. Hasil pembuatan rancangan mesin menggunakan software pro engineer dengan hasil dimensi sebagai berikut :
a. Panjang keseluruhan $600 \mathrm{~mm}$
b. Lebar keseluruhan $400 \mathrm{~mm}$
c. Tinggi keseluruhan $800 \mathrm{~mm}$

3. Hasil analisa perancangan menggunakan perhitungan sebagai berikut :

a. Berat total mesin yaitu $22,187 \mathrm{~kg}$

b. Kecepatan poros untuk memotong stainless steel 2 inchi yaitu $85 \mathrm{rpm}$

c. Kecepatan potong mesin ini adalah 12,5757 $\mathrm{mm} / \mathrm{min}$

d. Pemakanan material perputaran $0,053 \mathrm{~mm} / \mathrm{rev}$

e. Pengikisan terhadap waktu $14,82989423 \mathrm{~mm}^{3} / \mathrm{min}$

f. Daya berdasarkan gaya potong yaitu $0,5 \mathrm{~kW}$

g. Poros penggerak sebesar $9 \mathrm{~mm}$

h. Poros yang digerakan sebesar $18 \mathrm{~mm}$

i. Rantai yang dipakai adalah SCR0404

j. Diameter sproket besar 68,8 dengan mata gigi 34

k. Diameter sproket kecil 34,5 dengan mata gigi 17

1. Kecepatan rantai $1,2 \mathrm{~m} / \mathrm{s}$

Berdasarkan kesimpulan perancangan mesin, maka penulis merekomendasikan berupa saran-saran sebagai berikut :

1. Perlu dikembangkan lagi disain transmisinya

2. Diperlukan analisa disain menggunakan softwareuntuk membantu mengalanalisa rancangan.
[1] P. Gerhard and B. Wolfgang, "Engineering Design A systematic Approach”, London, Springer-Verlag, 1996.

[2] Sularso and S. Kiyokatsu, "Design of Machine Elements", PT. Pradnya Paramitra, Jakarta, 2002.

[3] Tata Surdia, Saito Shinroku.Pengetahuan Bahan, Material Teknik, PT. Pradnya Paramitra Jakarta 1999.

[4] Lawrence H. Van Vlack. (terjemahan) Ilmu dan Teknologi Bahan, Ilmu logam dan Bukan logam, PT.Erlangga Jakarta 1995.

[5] Khurmi R.S., Gupta J.K. (1977), Machine Design, First Edition. Ram Nagar, New Delhi 2005.

[6] BOSCH. (2013), Range catalogue Proffesional Accesoris Holesawing, (E-book) Jakarta (Juli 2017).

[7] SANDVIK COROMAT.(2013), Knowlege Drilling Formula, Definition and Formulas (E-book). Jakarta (Juli 2017).

[8] DID CHAINS (2012), Daido Chain Catalogue, Silent Chain and specifications, (E-book). Jakarta (Juli 2017).

[9] SKF Bearing. (2016), Rolling Bearing SKF catalogue, Standards and Specifications (E-book). Jakarta (Juli 2017).

\section{REFERENSI}

